IRA-International Journal of Education \& Multidisciplinary Studies

ISSN 2455-2526; Vol.07, Issue 02 (2017)

Pg. no. $160-165$

Institute of Research Advances

http://research-advances.org/index.php/IJEMS

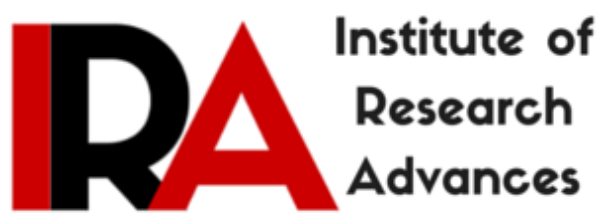

\title{
Performance Appraisal and Role of the Lamp Co-operative Societies in Tribal Areas in Karnataka
}

\section{Usharani B}

Research Scholar, Department of Studies and Research in Sociology, Mangalore University, Mangalagangothri, India.

Type of Review: Peer Reviewed.

DOI: http://dx.doi.org/10.21013/jems.v7.n2.p12

\section{How to cite this paper:}

Usharani, B. (2017). Performance Appraisal and Role of the Lamp Co-operative Societies in Tribal Areas in Karnataka. IRA International Journal of Education and Multidisciplinary Studies (ISSN 2455-2526), 7(2), 160-165. doi:http://dx.doi.org/10.21013/jems.v7.n2.p12

(C) Author.

\section{(cc) EY-NC}

This work is licensed under a Creative Commons Attribution-Non Commercial 4.0 International License subject to proper citation to the publication source of the work.

Disclaimer: The scholarly papers as reviewed and published by the Institute of Research Advances (IRA) are the views and opinions of their respective authors and are not the views or opinions of the IRA. The IRA disclaims of any harm or loss caused due to the published content to any party. 


\begin{abstract}
This study presents the role of co-operative Societies in general and a specific study on Karnataka. The Large Sized Agricultural Multi-purpose Co-operative Societies (LAMPS) are organised at the village level to meet the credit and other requirements of the tribal people. Tribal beneficiaries are the members LAMP Societies and they have benefited almost all the integrated services offered by the LAMPS for their economic upliftment. This study highlights the history, trends and growth of cooperatives. It also highlights the national policies, problems and suggests measures for the existence and viability of co-operative institutions, designed specifically for the welfare of the common man in general and for upliftment of tribes and weaker sections of the society in particular. The important aspect of examining the cause and effects of tribal economy has not been covered in any of the abovementioned studies. It is found from the review of literature that only a few researchers has studied the role of tribal co-operatives and their cause and effects on economic development of tribes.

This study is an empirical and field based, interview techniques are used for the collection of required data on the problem from the sample tribal respondents. The present study is also an attempt to go into the problems and prospects of co-operatives for the upliftment of tribals of Karnataka.
\end{abstract}

Key Words: LAMPS, Tribal Economy, Co-operative Societies, National Policies, Karnataka

In the context of tribal development, it is not merely the development of tribal areas but also the development of quality of life of the rural masses into self reliant and self sustaining communities. Therefore, tribal development implies the development of tribal areas in such a way that each component of tribal life changed in a desired direction. Besides, tribal development also encompasses structural changes in the Socio-economic situation in the rural tribal dominated regions by which human welfare is secured. Thus tribal development should include all objectives of enrichment and betterment of quality of rural masses through suitable development of resources, infrastructure and livelihood.

\title{
Tribes in India
}

India is a heterogeneous country in terms of language, religion, region, caste, tribe, race etc. Tribal Communities is one of the important segments of this nation. According to 2001 census of India, the tribal population is about 84.3 million, constituting about $8.2 \%$ of India's population. Tribal population in India is second in the world, next to Africa. There are 577 communities throughout the country recognized by the government as Scheduled Tribes; some of them are sub-tribes of larger tribes. The various tribal communities represent different regions with diverse cultures. There are also broad similarities in between these divergent tribes. Though vast number of tribal communities are scattered all over the country, most of them are concentrated heavily in forest areas. The economy of most of the tribes is subsistence agriculture or hunting and food gathering. Most of the tribes are economically, politically backward and they belong to weaker sections of the Indian society.

The tribals are economically weak and socially exploited by the middleman, money lenders and petty traders because of inadequate arrangement or providing credit and marketing of agricultural and forest produce in the tribal areas. Therefore, the planners and policy makers have taken efforts to organise and develop the Co-operative in the tribal regions to accelerate the process of tribal development.

\section{Tribes in Karnataka}

In Karnataka State according to the recent Census Report, 49 communities have been included in the list of Scheduled Tribes and very recently Siddi community of Uttara Kannada has been listed in the list of Scheduled Tribes. At present officially there are 50 Scheduled Tribe communities in Karnataka. There are some other tribal communities which have tribal characteristics but they have not been officially listed in the list of Scheduled Tribes, due to identity crisis. According to 2001 census tribes constitute $6.55 \%$ of the total population of the state. 
The concentration of tribes is high (according to 2001 census) in the districts of Raichur (18.14\%), Bellary (17.98\%), Chitradurga (17.53\%), Bidar (12.12\%), Davanagere (11.70\%), Koppal (11.58\%), Chamaraj Nagar (10.99\%) and Mysore (10.27\%), where their population varies between 10 to 18 percent compared to the total population. In Haveri (8.83\%), Kolar (8.11\%), Kodagu $(8.40 \%)$, Tumkur (7.49\%), Belgaum (5.77\%) and Gadag (5.59\%) districts, the percentage of Scheduled Tribe population is 5 to 10 percent. In Bagalkot (4.85\%), Gulbarga (4.92\%), Dharwad (4.39\%), Shivamogga (3.40\%), Udupi (3.74\%), Chikkamagalur (3.59\%), Bangalore Rural (3.27\%), Dakshina Kannada (3.31\%), Bijou (1.66\%), Hassan (1.53\%), Bangalore Urban $(1.31 \%)$ and Uttara Kannada $(1.75 \%)$, they constitute between 1 percent to 5 percent. However, in Mandya (0.97\%) district tribal population is below 1 percent.

Among the 50 communities listed in the list of Scheduled Tribes, Naiks or Nayaka constitute in highest percent followed by Kadu Kuruba, Marathi Naik, Gondas, Kolidar and Jenu Kurubas, Koya, Yeravas, Meda, Soliga, Koragas, Hasalaru and Siddis constitute relatively less in number.

\section{Co-operative Societies}

Co-operatives have been conceived as a shield to the weak and one of the major thrusts of Cooperative development programmes has been to ensure that benefits of the Co-operative flow increasingly to weaker sections including the Scheduled Tribes. The Co-operative have strived to achieve this through expansion of the membership of the weaker sections in the existing PACS and ensuring larger flow of funds and services to them. In this regard, specialised and functional Cooperative for activities like dairy, poultry keeping and fisheries have been organised. For forest labour, the forest labour corporations have been organised. Likewise, labour contract societies have also come up rural artisans have also of Co-operatives. In the tribals have come up in a big way in states like Madhya Pradesh and Andhra Pradesh. At the national level, the Tribal Co-operative Marketing Development Federation of India (TRIFED) was launched in 1987- 1988 to lend support to Tribal Co-operatives in marketing operations including price support incentives.

The Large-Scale Adivasi Multi-Purpose Societies (LAMPS) are co-operative Societies set up by the government for integrated tribal development in regions with significant tribal populations. They are generally one per taluka, and their membership is restricted to adult members of any Scheduled Tribe community. In a detailed analysis of the LAMPS in Karnataka (Lele and Rao 1996): The current functioning of the Large Scale Adivasi Multi-purpose Societies (LAMPS) in Karnataka are neither economically viable, socially empowering, nor ecologically sustainable.

There are 23 large sized Adivasi- Multi Purpose Co-operative Societies working in the state. These societies have been organised with the objective of improving the social and financial conditions of the Adivasis.

\section{These societies conduct the following activities}

- Collection and marketing of Minor Forest Produce by the Tribal people and improving the financial position by providing employment.

- Distribution of essential commodities and other consumer articles to its members and supply of food grains to the student hostels of SC and ST communities.

- Providing loans to its members and running processing units and other related activities.

The Statistical information pertaining to LAMPS Co-operative Societies is furnished below

\begin{tabular}{|r|l|r|}
\hline SI No & \multicolumn{1}{|c|}{ Items } & $2013-14$ \\
\hline 1 & No. of Lamps & 23 \\
\hline 2 & No.of members & 94452 \\
\hline 3 & Paid up Share Capital & 474.74 \\
\hline 4 & No. of societies working under profit & 20 \\
\hline
\end{tabular}




\begin{tabular}{|r|l|r|}
\hline 5 & No. of societies working under loss & $\mathbf{0 3}$ \\
\hline 6 & $\begin{array}{l}\text { Amount sanctioned by Govt. under } \\
\text { different schemes (including LAMPS } \\
\text { Federation) during 2013-14 }\end{array}$ & $\mathbf{5 5 . 7 7}$ \\
\hline
\end{tabular}

\section{Purpose of Tribal Co-operative Societies}

The purpose of the LAMPS and other tribal Co-operative is to offer multiplicity of services to the tribal population under one institutional set up. The services provided by their Co-operative include; Financial assistance, both short and medium term to meet the requirement of the tribals to carry on their agricultural operations and allied activities, financial assistance for consumption purpose, marketing assistance to the tribal to dispose of their agriculture and minor forest produce at remunerative price and distribution of agricultural inputs and consumer goods. It is found that not at all the Triabl Co-operatives in the region are geared to perform all these functions due to unique demographic conditions, life pattern of Tribals and other operational constraints.

Tribal development is a highly complex subject, which requires a multi-dimensional approach in which various ingredients like agriculture, industry, education, social-life living standards etc, have to be taken care. In the tribal development is an absolute and urgent necessity for the overall development of the economy.

\section{Review of literature}

A study of ten LAMP Societies (1979) was undertaken by the Reservation Bank of India in the State of Rajasthan which pointed out that area of LAMP was too large. They are weak in their functioning, managed by insufficient staff with no turnover and lack of co-ordination with District Central Cooperative Banks.

Mahalingam (1992) attempts to study the tribal co-operatives (LAMPS) in a North-East regions of India. He analysed the positive and negative aspect of Tribal Co-operatives in the studied region along with identification of factors which strengthen the Co-operative society in Tribal areas in those which weaken it. It has found that co-operative has helped the tribal people in the region in upgrading their economic status and quality of life through its integrated economic services.

Shah(1996) focuses a diverse range of co-operative ventures with a view to evolving a new explanatory framework to explain their relative success or failure in different contexts. The study draws upon cases from different fields as well as regions to develop a thesis that combines both social conditions both social conditions as well as design features.

\section{Objectives}

A co-operative is said to be a success only when it achieves success in both enterprise as well as institutional aspects. As such, the present study is conducted with the following objectives.

- To examine the Tribal Co-operative societies functioning have achieved their institutional objectives

- To identify the problems faced by the Tribal Co-operative societies functioning

- To suggest measures for improving the performance of Tribal Co-operative societies

\section{Methodology}

The study is based on both primary and secondary data. Primary data were collected from 180 participating members from Tribal Co-operative Societies functioning in Mysore District. A approach is employed for evaluating the performance of Scheduled Tribes Co-operative Societies in Mysore District. The success or failure of a co-operative organisation can be determined only by evaluating its achievements in the aspects of co-operative performance- institutional. 
Most of the tribes lived in remote villages and also because of illiteracy and low level of education of the tribal members; the researcher went to their residences and collected the required information. Before asking for information, a rapport was established with the respondents and the purpose of the survey was clearly explained to them. Then the researcher asked them questions in the local language and marked the information in the schedules.

\section{Findings}

The success of Scheduled Tribes Co-operatives is the institutional aspect is evaluated by analysing the socio-economic benefits enjoyed by the members. For this, data were obtained from the financial statements of the societies selected for detailed study. Discussions with government officials, Presidents and Secretaries of various Tribal co-operative societies were also made as part of the study. The present study is conducted with the principal objective of evaluating the performance of cooperative societies functioning and suggests measures to overcome the problems encountered by the societies.

- The LAMP co-operative societies in Mysore District could bring smal1 portion of the total tribal population in the district.

- The co-operative societies are functioning under the administrative control of different departments of the government. But the audit of all societies is conducted by the department of co-operation.

- There is no co-ordination among the different departments involved in the administration of co-operative societies.

- Financial assistances to the LAMPS co-operatives by the government are granted not on the basis of properly prepared projects.

- The share of females in the tribal population is more than that of the males. But in the membership of co-operatives the share of males is much higher than the share of females. So there is male domination in the membership of co-operatives.

- The low level of income of the members is the major reason for default in repayment.

- Director Board and General Body meetings are not held regularly.

\section{Suggestions}

- To implement the public distribution scheme to remote tribal areas properly and effectively and to reduce the losses, government should bear the transportation costs, handling charges and shortages etc....

- One central agency should collect and publish data relating to all the LAMP societies functioning in the state.

- Proper training should be imparted to the members for undertaking technical work.

If all the suggestions given above are sincerely and honestly implemented, the LAMP Co-operative societies will achieve their institutional objectives. An integrated approach to revamp and revitalize the Scheduled Tribe Co-operatives is a must.

\section{Conclusion}

Co-operatives are the democratic institutions aimed at eliminating economic disparities and poverty among the tribals. The economically weaker and the socially exploited tribals found some solace in the Co-operatives which help them to secure loan, market their produce and get agricultural inputs. But in the context of tribal development, social justice and empowerment of poor tribals it is indispensable that special provisions are to be made for ensuring concessional financial assistance through subsidised interest rate. But in the context of economy, finance percolating to the poor tribes are unsatisfactory due to leakages, misappropriation and corruption. Therefore, there should be dedicated and honest officials for promoting the cause of tribal development. 


\section{References}

- Lele. S, and J. Rao 1996. Whose co-operative and whose produce? The case of LAMPS in Karnataka

- Mahalingam, S. 1992. Tribal Co-operative. Rawat Publications:Jaipur.

- Mahalingam, S.1990 Role of Co-operative Organisation in Developing Tribal Economy.Mittal Publications: New Delhi.

- Pandhy, Dwarik Nath. 2002. Role of Co-operatives for Tribal Development.Mohit Publications: New Delhi

- Shah, Tushar .1995. Marketing Farmers Co-operatives Work. Sage Publications: New Delhi.

- Shah, Tushar .1996.Catalysing Co-operation. Sage India Publication: New Delhi 